\title{
Potato glycoalkaloids detection based on conductometric sensor coupled to butyryl cholinesterase
}

\author{
E. A. Nazarenko, A. P. Soldatkin, C. Martelet', Ya. I. Korpan \\ Institute of Molecular Biology and Genetics National Academy of Sciences of Ukraine \\ 150 str. Acad. Zabolotnoho, Kyiv, 03143, Ukraine \\ 1 \\ Ecole Centrale de Lyon \\ IFoS UMR 5621, B. P. 163 , F-69134 Ecully Cedex, France \\ E-mail: ya_korpan@yahoo.com
}

\begin{abstract}
For the construction of a biosensor sensitive to some steroidal glycoalkaloids a conductometric planar electrode as a transducer and the horse serum butyryl cholinesterase (BuChE) as a biorecognition element have been used. It has been shown that $\alpha$-solanine, $\alpha$-chaconine and solanidine can be detected within the range of their concentrations from 0.2 to $100 \mu \mathrm{M}$ depending on the type of steroidal alkaloid used. The detection limits were estimated to be $0.2 \mu \mathrm{M}$ for chaconine and $0.5 \mu \mathrm{M}$ for solanine/solanidine. The responses of the sensors developed were reproducible: the relative standard deviation was about $1.5 \%$ and $5 \%$ for intra- and inter-sensor responses, respectively. Moreover, one sensor with the immobilized enzyme can be used repeatedly (for at least 100 measurements) after a simple washing by buffer and can be stored at room temperature without substantial loss in activity of the immobilized enzyme not less than I month It has been shown that all the analytes investigated inhibit reversibly and competitively the horse BuChE immobilized on the transducer surface. In assays, which combined $\alpha$-solanine and $\alpha$-chaconine, inhibition of $\mathrm{BuChE}$ was not additive. A possibility to apply the biosensor developed for the quantitative detection of the total steroidal alkaloids pool in foodstuffs and some biological samples is discussed.
\end{abstract}

Introduction. The cultivated potato (Solanum tuberosum L.), as one of the world's major agricultural crops, is consumed daily by millions of people from diverse cultural backgrounds. Potatoes are grown in $\sim 80 \%$ of all countries, and world-wide production stands in access of 350 million tones per annum, a figure exceeded only by wheat, maize and rice [1]. Despite its status as a food of global importance, the potato tuber contains toxic glycoalkaloids (GA) that cause sporadic outbreaks of poisoning in humans and a lot of livestock deaths [2]. Potatoes and individual alkaloids have been shown to be teratogenic; embryotoxic, and toxic $[3,4]$. It has been also found that GA specifically induces membrane disruptive effects on cholesterol containing membranes and are more potent in permeabilizing the outer membrane of (C) A. NAZARENKO, A. P. MOLDATKIN, C. MARTFILI,
Ya. I. KORYAN, 2004 mitochondria compared to digitonin. In vitro studies have revealed that solanine and chaconine inhibit substantially cholinesterase's activity as well [5]. Solanine non-competitively inhibit calcium transport in vivo in rat duodenum.

Either chaconine or solanine reduces the sodium ion active transport in frog skin [6, 7]. Their high concentration may cause acute poisoning, including gastrointestinal and neurological disturbances, in man, with death being caused by the central nervous system depression. Other studies also suggest that there is an increased risk for cancers of the brain, breast, endometrium, lung, and thyroid associated with the consumption of large quantities of potatoes [8]. An available information suggests that the susceptibility of humans to GA poisoning is both high and very variable: oral doses in the range of $1-$ $5 \mathrm{mg} / \mathrm{K}$ body weight are marginally to severely toxic to humans whereas $3-6 \mathrm{mg} / \mathrm{Kr}$ body weights can be 
lethal [9]. Neither chaconine nor solanine levels are affected by food processing and preparation. On the contrary, baking and frying, resulting in low moisture-containing products, considerably concentrate GA in products such as potato chips and fried peel, and the risk of possible toxicity increases greatly [10]. The widely accepted safety limit for GA in tubers remains $200 \mathrm{mg} / \mathrm{Kr}$ fresh weight.

However, owing the large and often unpredictable variations in the GA levels, which can arise from differences in variety, locality, cultural practices and stress factors (light, disease, mechanical injury, conditions of storage and pre-treatment, insect damage and chemicals), and the fact that so many aspects of biochemistry and toxicity of these compounds remain poorly understood, the World Health Organization has proposed that the limit should be reduced to $20-100 \mathrm{mg} / \mathrm{kg}$. We agree completely with Parnell et al. [11] that «many authors have assumed without further evidence that levels below $200 \mathrm{mg} / \mathrm{kg}$ are safe. They ignore the fact that the $200 \mathrm{mg} / \mathrm{kg}$ [FW] level only relates to acute and/or subacute effects and not to possible chronic effects...».

These considerations are sufficient to make obvious the necessity for the GA control in the fields of agriculture, food analysis and health care.

The methods in current use for the determination of GA include colorimetry [12], thin-layer chromatography $[13]$, gas chromatography $[14]$, mass spectrometry $[15]$, liquid chromatography $[16]$, high performance liquid chromatography [9, 17], high performance thin layer chromatography $[18]$ and immunoassays [19]. It must be pointed out that each method has its relative disadvantages. $\mathrm{GA}$ in potatoes are usually determined by liquid chromatography method including time-consuming sample preparation by solid phase extraction and non-specific UV detection at $202 \mathrm{~nm}$. Moreover, the relative standard deviations (RSD), obtained for the alkaloids detection by this method, are ranging from 8 to $13 \%[16]$. In addition, GA do not contain strong chromophores, and a derivatisation step is generally needed to determine them.

ELISA $[20]$ is extensively used to analyze the total GA fraction. Extraction of the alkaloids prior to assay is simple solubilisation, making the whole procedure much quicker than alternative methods. It is carried out in the wells of plastic microtitration plates. The immunoassay procedure is often extremely specific, technically simple and does not require the services of an experienced analyst. However, the main problem of immunoassay is the high price of the biologically active material, i. e. monoclonal antibodies and enzyme-labeled antibodies. Biosensors

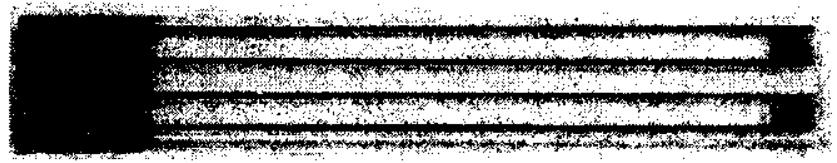

Fig. 1. General view of platinum interdigitated planar electrodes used for the development of alkaloid-specific biosensor

seem to be a very promising tool to overcome most of the problems described above. A basic idea for the ISFET-based monitoring of $\alpha$-solanine, $\alpha$-chaconine and solanidine has been proposed by Korpan et al. [21], and recently optimised by Arkhypova et al. [22].

Owing to simplicity of the technologies of planar electrodes production in comparison with ISFET, the objective of this study was to develop the alkaloid sensitive conductometric sensor coupled to $\mathrm{BuChE}$, to investigate the main analytical characteristics of the biosensor developed and to study the mechanism of the immobilized BuChE inhibition by GA.

Materials and Methods. Chemicals. Butyryl cholinesterase (pseudocholinesterase EC 3.1.1.8) from horse serum, $13 \mathrm{U} / \mathrm{mg}$ solid; butyrylcholine chloride $(\mathrm{BuChCl})$; bovine serum albumin (BSA, fraction $\mathrm{V}$, $98 \%$ purity); $\alpha$-chaconine, $\alpha$-solanine and solanidine from potato sprouts were purchased from «Sigma» (France). Aqueous solution $(25 \% \mathrm{w} / \mathrm{v})$ of glutaraldehyde (GIA) was obtained from «Sigma-Aldrich Chemie GmbH» (Germany). All other chemicals were of analytical grade and were used without any further treatment.

The alkaloids ( $\alpha$-chaconine, $\alpha$-solanine and solanidine) were prepared as $1 \mathrm{mM}$ solutions in $5 \mathrm{mM}$ acetic acid solution.

Sensor design. The planar electrodes (Fig. 1) consist of two identical pairs of platinum interdigitated electrodes on a glass substrate (thickness $0.5 \mathrm{~mm}$, dimensions $5 \times 40 \mathrm{~mm}$ ). The sensitive area of each electrode pair was about $1 \times 1.5 \mathrm{~mm}$. These electrodes were used as transducers for conductometric measurements.

Enzyme immobilization. A biologically active membrane on the transducer surface was formed by a method of protein cross-linking in saturated GlA vapour [24]. The mixture containing $5 \%(w / v)$ $\mathrm{BuChE}, 5 \%(\mathrm{w} / \mathrm{v}) \mathrm{BSA}$ and $10 \%(\mathrm{v} / \mathrm{v})$ glycerol in $20 \mathrm{mM}$ phosphate buffer ( $\mathrm{pH} 7.5$ ) was deposited in a drop wise way on the sensitive surface of a measuring sensitive element, while the mixture containing $10 \%$ $(\mathrm{w} / \mathrm{v})$ BSA and $10 \%(\mathrm{v} / \mathrm{v})$ glycerol in $20 \mathrm{mM}$ phosphate buffer $(\mathrm{pH} 7.5$ ) was placed on a reference element. Then, the conductometric transducers were placed for $30 \mathrm{~min}$ in saturated GlA vapour. After exposure to GIA, the membranes were dried at room temperature for $30 \mathrm{~min}$ and before measurements the 


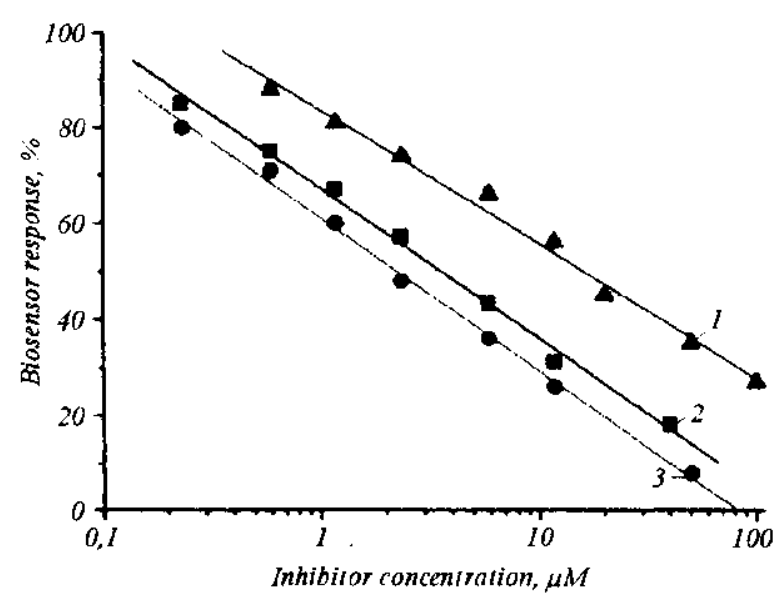

Fig. 2. Calibration curves for the detection of solanine $(I)$, chaconine (2) and equimolar mixture of solanine and chaconine (3) by the conductometric sensor coupled to BuChE. Measurement conditions: $10 \mathrm{mM} \mathrm{K}, \mathrm{Na}$-phosphate buffer, $\mathrm{pH} 7.5$, room temperature and $\mathrm{BuChCl}$ concentration of $10 \mathrm{mM}$

membranes were soaked for $20 \mathrm{~min}$ in a buffer solution to equilibrate the membrane system. After use, the membranes containing biologically active material were washed twice with buffer solution, dried and stored at 4 or $20{ }^{\circ} \mathrm{C}$.

Measurement of enzyme activity and inhibition. Measurements were conducted in daylight at room temperature $\left(20^{\circ} \mathrm{C}\right)$ in a glass cell $(2 \mathrm{ml}$ volume) filled with $\mathrm{K}, \mathrm{Na}$-phosphate buffer, $\mathrm{pH}$ 7.5. The biosensor was immersed in a vigorously stirred sample solution. After baseline stabilization, $\mathrm{BuChCl}$ was added to the vessel. The differential output signal between the measuring and reference sensitive elements was registered with «home made» laboratory set-up, and the steady state or kinetic response of the biosensor was plotted as a function of the $\mathrm{BuChCl}$ concentration.

The evaluation of the enzyme inhibition by GA was carried out at an excess concentration of butyrylcholine chloride and included the following steps:

The biosensor was soaked in $5 \mathrm{mM} \mathrm{K}, \mathrm{Na}$-phosphate buffer, $\mathrm{pH} 7.5$, until reaching a stable baseline output signal;

Butyrylcholine chloride was added to the measurement cell. The kinetic or steady-state output signal of the biosensor was taken as an index of the maximal catalytic activity of the immobilized enzyme, and such a value of the biosensor response was used for further evaluation of the inhibition effect of a definite GA concentration;

After twice washing, the sensor output was registered in the buffered solution containing target steroidal alkaloid(s) and butyrylcholine chloride as described in the previous step. The level of inhibition due to the action of a definite concentration of GA was evaluated by comparison of the biosensor response levels without and with inhibitor.

Results and Discussion. Solanine and chaconine account for $95 \%$ of GA present in $S$. tuberosum and consist of a nonpolar lipophilic steroid nucleus that is extended by two fused nitrogen-containing heterocyclic rings at one end and bound to a polar water-soluble trisaccharide at the other. Recently [25], it has been established, that the GA action on the human plasma and serum $\mathrm{BuChE}$ is reversible inhibition of their activity. It is well known that BuChE hydrolyses butyrylcholine chloride according to the reaction:

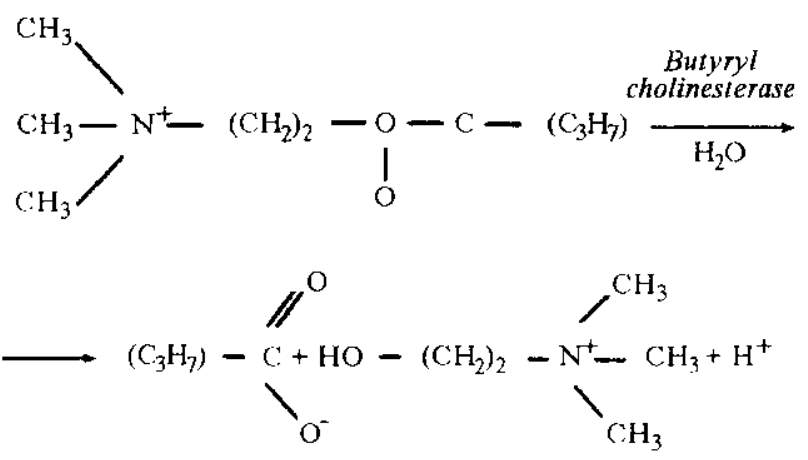

Thus, the charged products of this reaction can be detected by means of biosensors based on conductometric thin-film electrodes. GA can be detected using inhibitory methodology developed earlier for the detection of pesticides and heavy metal ions [26, 27]. The decrease in the electrochemical sensor output signal caused by the enzyme inhibition depends on the steroidal alkaloid concentration in the analysed sample.

The dependence of the enzyme inhibition on the GA concentration (Fig. 2) was investigated using conductometric transducers. As can be seen in Fig. 2, $\alpha$-solanine, $\alpha$-chaconine and mixture of solanidine and chaconine can be detected within the linear dynamic range (in semi logarithmic scale) of the inhibitor concentration from 0.2 to $100 \mu \mathrm{M}$. The detection limits were estimated to be $0.2 \mu \mathrm{M}$ for chaconine and $0.5 \mu \mathrm{M}$ for solanine/solanidine.

The proposed sensor like the potentiometric biosensor developed and optimised earlier [22] can be suitable for the quantitative detection of the total GA pool in foodstuffs samples as both types of transducers detect protons generated in the BuChE catalysed reaction. The ratio of solanidine:solanine:chaconine in blood, given in the Hellenas et al. [9] study, was $1: 2.4: 4.5$. Therefore, serum level [25] could be $0.19 \mu \mathrm{M}$ for solanidine, $0.2 \mu \mathrm{M}$ solanine, and $0.4 \mu \mathrm{M}$ 


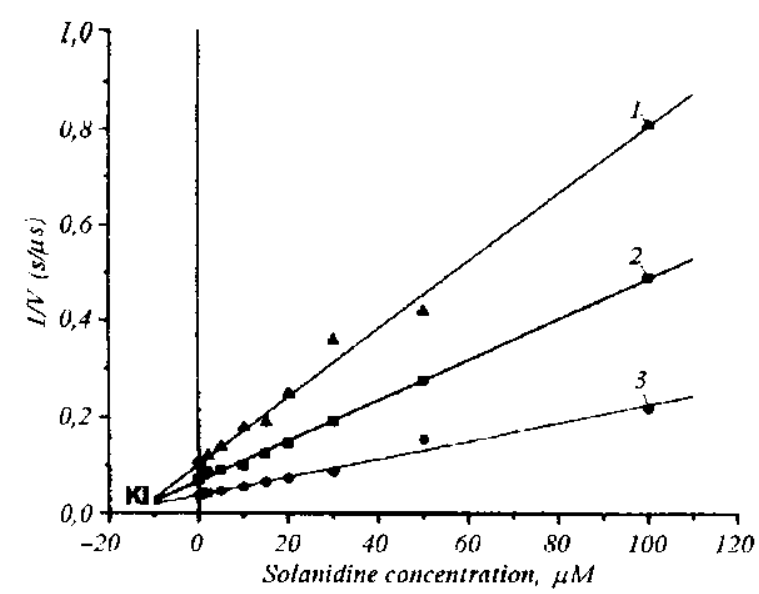

Fig. 3. Dixon graph for mesurement inhibiton constant by conductometric sensor coupled to BuChE. Measurements are made in 5 $\mathrm{mM} \mathrm{K,Na-phosphate} \mathrm{buffer,} \mathrm{pH} 7.4$ at room temperature, and at $0.5 \mathrm{mM}(I), 1.0 \mathrm{mM}$ (2) and $2.0 \mathrm{mM}$ (3) $\mathrm{BuChCl}$ concentrations

for chaconine. Assuming regular ingestion of potatoes, these concentrations [25] might lead to the liver concentration of solanidine $267 \mu \mathrm{M}$, solanine $293 \mu \mathrm{M}$ and chaconine $560 \mu \mathrm{M}$. Thus, the conductometric biosensor developed could also be proposed for the detection of alkaloids in tissues and blood serum that will be the objective of a next publication.

It has been shown that chaconine (Fig. 2) is a more potent inhibitor of immobilized butyryl cholinesterase than the other relative compound, solanine. Since both of them share the same aglycone, namely solanidine, it can be suggested that more strong effect of chaconine on the enzyme activity is associated with the differences in their carbohydrate component and in steric compatibility of the whole alkaloid molecule with the enzyme active site. In the assays, which combined of $\alpha$-solanine and $\alpha$-chaconine, inhibition of BuChE was not additive (Fig. 2) and these results are in good agreement with those obtained by Nigg et al. [25] for inhibition of the human plasma and serum BuChE. The results obtained (Fig. 2, curves 1 and 2) can be explained by the competition between the substrate and chaconine/solanine as well as by the competition between the inhibitors, and competition was proved by experimental estimation of $K_{i}$ values for solanine, chaconine and solanidine.

An example of the methodology used for the direct detection of $K_{i}$ value for solanidine is depicted in Fig. 3. Apparent $K_{i}$ values for solanine and chaconine were estimated in the same manner, the values for solanine, chaconine and solanidine being

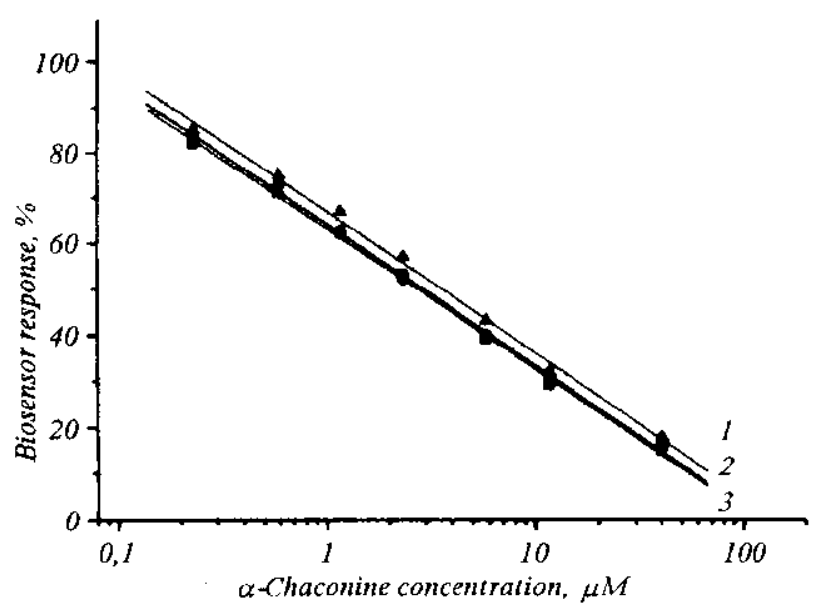

Fig. 4. Dependence of the conductometric sensor (relativei) response on buffer concentration. Measurement conditions: $5 \mathrm{mM}(I), 10 \mathrm{mM}$ (2) and $20 \mathrm{mM}$ (3) K,Na-phosphate buffer, pH 7.5, room temperature, $\mathrm{BuChCl}$ concentration of $10 \mathrm{mM}$

5.3, 6.4 and $12.6 \mu \mathrm{M}$, respectively. According to the results obtained one may assume that solanine occupies the active site of BuChE faster than other investigated compounds. The absence of the additive effect during simultaneous action of GA (Fig. 2, curve 3 ) is a characteristic of the competitive mechanism of inhibition. These results are not in a good agreement with those obtained by Alozie et al. [26], where chaconine was classified as a noncompetitive mixed type inhibitor for the rat cholinesterase isoenzymes. This can be explained by the difference in molecular structure of the esterases obtained from rat liver and horse serum.

One of the most crucial points for the biosensors based on ISFETs and planar electrodes is a strong dependence of their response on buffer concentration that usually results in an -10 -fold decrease in output signal when the concentration of buffer is changed

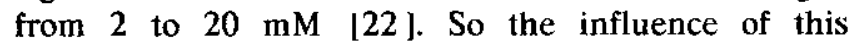
parameter on the response of the biosensor should be an extremely important taking into account that the conductometric sensor is planned to be used in such complicated media as potato juices, serum and tissues. It has been shown (Fig. 4) that the level of inhibition of BuChE immobilized on the surface of conductometric transducers virtually does not depend on the buffer concentration, thus the variation in buffer concentration is not an important parameter for the GA determination and thus allow the application of the biosensor proposed in such complicated media like potato juices [22] and biological samples.

The response of the GA sensitive planar elec- 


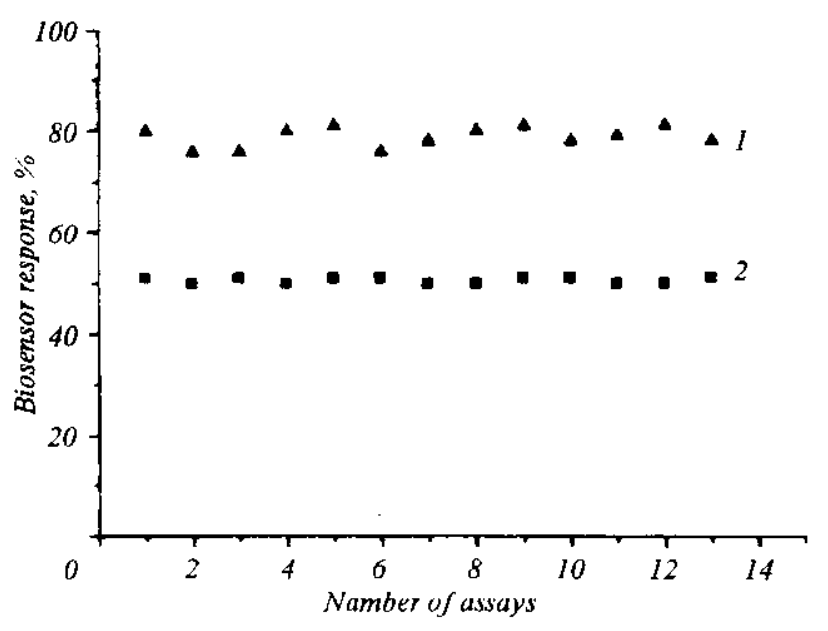

Fig. 5. Reproducibility of the $a$-chaconine detection by the con ductometric sensor. Measurement conditions are the same as in Fig. 2 . Inhibitor concentration: $1 \mu \mathrm{M}$ for inter-sensor response $(l)$ and $6 \mu \mathrm{M}$ for intra-sensor response (2)

trode-based biosensors is reproducible (Fig. 5). The relative standard deviation of intra-sensor responses being $1.5 \%(n=10$, at the GA concentration $6 \mu \mathrm{M})$ while the relative standard deviation of inter-sensor responses was $5 \%$. Moreover, the same sensor with immobilized enzyme can be used repeatedly (for at least 100 measurements) after a simple washing by phosphate buffer, and can be stored at room temperature not less than one month without substantial loss in the activity of $\mathrm{BuChE}$. When stored in $10 \mathrm{mM}$ phosphate buffer $(\mathrm{pH} 7.5)$ at $4{ }^{\circ} \mathrm{C}$, the sensor responses remain stable for more than three months.

Conclusions. A methodology for the detection of steroidal GA based on the conductometric sensor coupled to $\mathrm{BuChE}$ has been developed. In contrast to all the methods routinely used, the biosensor method is rather cheap, fast and reliable. Contrary to the developed BuChE-based electrochemical sensors for organophosphorous pesticides [27] and heavy metal ions determination [28], the biosensor proposed does not need scavenging agents for the enzyme activity restoration and is quite stable during the storage and operation.

Moreover, since the specificity of BuChE to other inhibitors, especially heavy metal ions and pesticides is low, an attention should be paid further to the adjustment of the proposed sensor specificity.

Acknowledgements. The authors wish to thank NATO (Grant \# LST.CLG.977342), INTAS (Grant \# 00-00151) and National Academy of Sciences of Ukraine (Project 2.2.4.18) for financial support of this research.
О. А. Назаренко, О. П. Солдаткін, К. Мартле, Я. І. Корпан

Визначення глікоалкалоїдів картоплі кондуктометричними сенсорами на основі бутирилхолінестерази

Резюме

При створенні біосенсора, чутливого до стероїдих глікоалкалоїдів, застосовано кондуктометричний планарний електрод як перетворювач $і$ бутирилхолінестеразу (БуХЕ) як чутливий елемент. Соланін, чаконін та соланідин визначали в діапазоні концентрацій 0,2-100 мкм залежно від типу алка лоїду. Мікімальні концентрації, які визначаються за допомогою біосенсора, становлять 0,2 мкМ для чаконіну та 0,5 мкМ для соланіну/соланідину. Відносні стандартні внутріиньь- та міжсенсорні похибки складали 1,5 та 5 \% відповідно. Крім того, той самий сенсор з іммобілізованим ферментом після відмивання в буфері можна багаторазово використовувати (цонаймение 100 виміріз) та зберігати за кімнатної температури без суттсвого зменшення активності іммобілізованого ферменту протягом місяия. Доведено, цо всі досліджені речовини конкурентно та оборотно пригнічують кінську БуХЕ, іммобілізовану на поверхні перетворювача. При дослідженні спільної дії $\alpha$-соланіну та $\alpha$-цаконіну додаткового пригкічення БуХЕ не спостерігалося. Обговорюсться можливість застосування розробленого біосенсора для кількісного визначення загальної фракції стероӥдних глікоалкалоїдів у харцових продуктах та деяких біологічних зразках.

Е. А. Назаренко, А. П. Солдаткин, К. Мартле, Я. И. Корпан

Определение гликоалкалоидов картофеля кондуктометрическими сенсорами на основе бутирилхолинэстеразы

Резюме

Для создания биосенсора, чувствительного к стероидным гли коалкалоидам, использовали кондуктометрический планарный электрод в качестве преобразователя и бутирилхолинэстеразу (БуХЭ) как иувствительный элемент. Соланин, наконин и соланидин определяли в диапазоне концентраций $0,2-100$ мкМ в зависимости от типа алкалоида. Минимально определяемая концентрация для чаконина - 0,2 мкM, для соланина/ соланидина 0,5 мкМ. Относительные стандартные внутри- и межсенсорные оиибки составили 1,5 и $5 \%$ соответственно. Кроме того, один и тот же сенсор с иммобилизованным ферментом после простого отмывания буфером можно многоразово использовать (по меньией мере, 100 измерений) и хранить при комнатной температуре без значительной потери активности иммобилизованного фермента в течение месяца. Показано, что исследуемые вещества конкурентно и обра тимо ингибируют лошадиную БуХє, иммобилизованную на поверхности преобразователя. При исследовании совместного действия $\alpha$-соланина и $\alpha$-чаконина дополнительного инсибирования БуХЭ не наблюдалось. Обсуждается возможность применения разработанного биосенсора для количественного определения общей фракции стероидных гликоалкалоидов в пищевых продуктах и некоторых биологических образцах.

\section{REFERENCES}

1. FAQ Production Yearbook, Food and agricultural organization of the United Nations.-Rome, 1992.-Vol. 46.

2. Smith D. B., Roddick J. G., Jones J. Leighton potato glycoalkaloids: Someunswered question // Food Sci. and Technol.-1996.-7.-P. 126-131.

3. Morris S. C., Lee T. H. The toxicity and teratogenicity of 
Solanaceae glycoalkaloids, particularly those of the potato (Solanum tuberosum) // Food Technol. Austral.-1984.-36, N 3.-P. 118-124.

4. Slanina $P$. Solanine (glicoalkaloids) in potatoes: Toxicological evaluation // Food and Chem. Toxicol. $-1990 .-28$, N 11.P. 578-579.

5. Nigg H. H., Beier R. C. Evaluation of food for potential toxicants // R. C. Amer. Soc. Plant Physiol.-1995.-15.-. P. $192-201$.

6. Friedman M., McDonald G. Potato glycoalkaloids: chemistry, analysis, safety, and plant physiology // Crit. Rev. Plant Sci. -1997 . - 16. - P. 55-132.

7. Blankemeyer J. Y., Atherton R., Friedman M. A screening method for the determination of glycoalkaloids in tubers of potato varieties // J. Agr. Food and Chem.-1995.-43.P. $636-639$.

8. Report of National Institute of Environmental Health Sciences (USA).-New York, 1999.-200 p.

9. Hellenas K.-E., Nyman A., Slanina P., Loof L., Gabrielsson $J$. Determination of potato glycoalkaloids and their aglycone in blood serum by high-performance liquid chromatography: Application to pharmacokinetic studies in humans // J. Chromatogr. $-1992 .-573 .-$ P. $69-78$.

10. Zhao J., Camire M. E., Bushway R. J., Bushway A. A. Glycoalkaloid content and in vitro glycoalkaloid solubility of extruded potato peels // J. Agr. and Food. Chem.-1994.42.-P. 2570-2573.

11. Parnell A., Bhuva V. S., Bintcliffe E. J.B. The glycoalkaloid content of potato varieties // J. Nat. Inst. Agr. Bot. - 1984.16. -P. $535-541$.

12. Clement E., Verbist J. F. Determination of solanine in Solanum tuberosum // Lebensmitt.-Wiss. + Technol.-1989.13. -P. 202-206.

13. Ferreira F, Moyna P., Soule $S$. Rapid determination of Solanum glycualkaloids by thin-layer chromatographic scanning // Chromatography. $-1993 .-53 .-P$. 380-384.

14. Herb S. F., Fitzpatrick T. J., Osman S. F. Separation of potato glycoalkaloids by gas chromatography // J. Agr. Food and Chem. -1975 . -23.-P. 520-523.

15. Chen S., Derrick P. J., Mellon F. A. Analysis of glycoalkaloids from potato shoots and tomatoes by four-sector tandem mass spectrometry with scanning-array detection: comparison of positive ion and negative ion methods // Anal. Biochem.1994.-218.-P. 157-169.

16. Hellenas $K_{-}-E$, Branzell $C$. Liquid chromatographic determination of the glycoalkaloids alpha-solanine and alphachaconine in potato tubers: MNKL Inter-laboratory Study. Nordic Committee on Food Analysis // J. AOAC Int.-1997. 80.-P. 549-554.

17. Sotelo B., Serrano J. High-performance liquid chromatographic determination of the glycoalkaloids alpha-solanine and alpha-chaconine in 12 commercial varieties of Mexican potato // J. Agr. and Food Chem.-2000.-48.-P. 2472-2475.

18. Simonovska B., Vovk $I$. High-performance thin-layer chromatographic determination of potato glycoalkaloids // J. Chromatogr.-2000.-903.-P. 219--225.

19. Pat. USA. US 5614408. Monoclonal antibodies to potato, tomato and eggplant glycoalkaloids and assays for the same / L. H. Stanker, C. K. Holtzapple // Publ. 1997.

20. Pihak L, Sporns P. Enzyme immunoassay for potato glycoalkaloids. $/ /$ J. Agr. and Food Chem.-1992.-40.P. $2533-2540$.

21. Korpan Y. I., Volotovsky V. V., Martelet C., Jaffresic-Renault N., Nazarenko E. A., El skaya A. V., Soldatkin A. P. A novel enzyme biosensor for steroidal glycoalkaloids detection based on pH-sensitive field effect transistors // Bioelectrochemistry. $-2002 .-55 .-$ P. 9-11.

22. Arkhypova V. N., Dzyadevych S, V., Soldatkin A. P., El'skaya $A$. V., Martelet C., Jaffrezic-Renault $N$. Development and optimization of biosensors based on pH-sensitive field effect transistors and cholinesterases for sensitive detection of Solanaceous glycoalkaloids // Biosensors and Bioelectronics.2003.-18.-P. 1047-1050.

23. Shut'ga A. A., Netchiporouk L. I., Sandrovsky A. K., Abalov A. A., Frolov O. S., Kononenko Yu. G., Maupas H., Martelet C. Operation of an ISFET with non-insulated substrate directly exposed to the solution // Sensors and Actuators.-1995.30. -P. $101-105$.

24. Pat. French. \# 9305941 . Capteur e’lectrochimique de dosage enzymatique de type ENFET et dispositif de dosage le mettant en ceuvre / A. Soldatkin, C. Shul'ga, N. Martelet, H. Jaffresic-Renault, A. Maupas, A. El'skaya // P'ubl. 1993.

25. Nigg H. N., Ramos L. E., Graham E. M., Sterling J., Brown $S$., Cornell J. A. Inhibition of human plasma and serum butyrylcholinesterase (EC 3.1.1.8.) by $\alpha$-chaconine and $\alpha$ solanine // Fundatn. and Appl. Toxicol.-1996.-33.P. $272-281$.

26. Alozie S. O., Sharma R. P., Salunkhe D. K. Inhibition of rat cholinesterase isoenzymes in vitro and in vivo by the potato alkaloid $\alpha$-chaconine // J. Food Biochem.-1979.-2.P. $259-276$.

27. Zhylyak G. A., Dzyadevich S. V., Korpan Y. I., Soldatkin A. P., El'skaya A. V. Application of urease conductometric biosensor heavy-metal ion determination // Sensors and Actuators. - 1995.-24.-P. 145-148.

28. Dzyadevich S. V., Arkhypova V. N., Elskaya A. V., Martelet C., Jaffrezic-Renault N., Soldatkin A. P. Conductometric enzyme biosensors for substrates and inhibitors analysis // Curr. Top. Anal. Chem.-2001.-2.-P. 179-186.

УДК $547.94+612.047$ Надійшла до редакції 26.12.03 